\title{
$\begin{array}{ll}\text { Research Square } & \begin{array}{l}\text { Preprints are preliminary reports that have not undergone peer review. } \\ \text { They should not be considered conclusive, used to inform clinical practice, } \\ \text { or referenced by the media as validated information. }\end{array}\end{array}$
}

\section{Photodegradation of methotrexate in aqueous solution: degradation kinetics and identification of transformation products}

\section{Anaïs Espinosa}

INRAE Île-de-France-Versailles-Grignon: Institut National de Recherche pour l'Agriculture l'Alimentation et l'Environnement Centre lle-de-France-Versailles-Grignon

\section{Sylvie Nélieu ( $\sim$ sylvie.nelieu@inra.fr)}

INRAE Île-de-France-Versailles-Grignon: Institut National de Recherche pour l'Agriculture l'Alimentation et l'Environnement Centre lle-de-France-Versailles-Grignon https://orcid.org/0000-0002-3677-7300

\section{Pascale Lieben}

INRAE Île-de-France-Versailles-Grignon: Institut National de Recherche pour l'Agriculture l'Alimentation et l'Environnement Centre lle-de-France-Versailles-Grignon

\section{Charles Skarbek}

Université Paris-Sud: Universite Paris-Saclay

\section{Raphaël Labruère}

Université Paris-Sud: Universite Paris-Saclay

\section{Pierre Benoit}

INRAE Île-de-France-Versailles-Grignon: Institut National de Recherche pour l'Agriculture l'Alimentation et l'Environnement Centre lle-de-France-Versailles-Grignon

\section{Research Article}

Keywords: Methotrexate, Anticancer drug, Photo irradiation, Transformation products, Structural identification, Degradation pathway, Cytotoxicity

Posted Date: April 12th, 2021

DOI: https://doi.org/10.21203/rs.3.rs-303070/v1

License: @ (i) This work is licensed under a Creative Commons Attribution 4.0 International License. Read Full License

Version of Record: A version of this preprint was published at Environmental Science and Pollution Research on August 25th, 2021. See the published version at https://doi.org/10.1007/s11356-021-15820-3. 


\section{Abstract}

Methotrexate is an antineoplastic folate analog of high environmental concern, due to its low biodegradability and toxicological properties. This study focused on its photodegradation under two irradiation conditions, aiming to be representative of environment (300-450 nm) and drinking water treatment (254 nm). The photodegradation experiments were conducted at two $\mathrm{pH}$, to vary the methotrexate ionization state and to produce a large variety of transformation products (TPS). The degradation kinetics determined through LC-UV monitoring were contrasted according to $\mathrm{pH}$ and irradiation wavelength. However, the quantum yields were independent of ionization state at $254 \mathrm{~nm}$ and the changes in kinetics at higher wavelengths were attributed to a change in the degradation mechanism. The TPs formed during the reactions were identified by UHPLC-MS/MS, using both the positive and negative modes. Among the eleven proposed structures, five were described as methotrexate TPs for the first time. The TPs result from N-demethylation, glutamic acid oxidation and $\mathrm{C}-\mathrm{N}$ cleavage, all of them leading to further degraded photoproducts presenting modified or lost glutamic acid part. This was made possible thanks to the negative mode, which allowed the exploration of the glutamic acid moiety modifications. Cytotoxicity assessment on A549 cancer cells demonstrated that all photoproducts formed at pH 7 were less toxic than the parent compound.

\section{Introduction}

Pharmaceuticals and their degradation products are detected in surface waters, wastewater and groundwater at a range of $\mathrm{ng} / \mathrm{L}$ to $\mathrm{mg} / \mathrm{L}$ (aus der Beek et al. 2016) and even in drinking waters (Benotti et al. 2009; Mompelat et al. 2011). These occurrences are mainly due to their pharmacokinetics since pharmaceuticals are excreted by patients either as the parent compound (60\%-95\% - Turci et al. 2003) or as metabolites before entering domestic wastewaters. Discharges from municipal sewage effluents are considered as the main source of pharmaceuticals in the environment (Garcia-Ac et al. 2009a) since they represent $80 \%$ of their release against $20 \%$ for hospital waste waters (Besse et al. 2012). Castiglioni et al. (2005) detected nineteen pharmaceuticals in concentrations ranging from 0.5 to $2000 \mathrm{ng} / \mathrm{L}$ in Waste Water Treatment Plant (WWTP). Parent compounds, metabolites and transformation products (TP) formed by oxidative techniques such as ozonation, UV/hydrogen peroxide treatment and chlorination can enter in surface waters due to their incomplete degradation during wastewater treatment. Escher and Fenner (2011) have shown that knowledge about TP and metabolites can be relevant for environmental risk assessment because they can be more persistent, more mobile or have a higher toxicity than the parent compound.

Among various classes of pharmaceuticals, antineoplastic agents are of particular environmental concern due to their highly potent mechanism of action: they are cytotoxic, genotoxic, mutagenic and teratogenic (Zounková et al. 2007). They have been detected in source waters at pg/L range for oxazaphosphorines for example (Buerge et al. 2006). The most investigated anti-cancer drug is cyclophosphamide (Besse et al. 2012), but another anticancer drug: methotrexate $((2 S)-2-[(4-\{[(2,4-$ diaminopteridin-6-yl)methyl](methyl)amino\}benzoyl)amino] pentanedioic acid, MTX) is one of the most widely prescribed antineoplastic agents worldwide. It has been used for more than 50 years (Lai et al. 2017) in treatments of meningingeal leukemia, psoriasis and rheumatoid arthritis (Sabry et al. 2003). It competitively inhibits dihydrofolate reductase, the enzyme that reduces dihydrofolates to tetrahydrofolates. The reduced folate derivatives are important coenzymes in the biosynthesis of amino acids and the purine and pyrimidine units of DNA (Breithaupt et al. 1982).

Methotrexate (MTX) is mostly excreted unchanged (80\%-90\%) after administration to patient (Garcia-Ac et al. 2009a) and the main metabolites are the 7-hydroxymethotrexate (7-OH-MTX), the 2,4-diamino-N(10)-methylpteroic acid (DAMPA) and the polyglutamylated forms (Widemann et al. 2000). DAMPA is known as a minor and inactive metabolite of MTX since it does not inhibit human dihydrofolate reductase (Donehower et al. 1979; Widemann et al. 2000). However, 7-OH-MTX is included in the priority list for environmental assessment due to its persistence and toxicity (Besse et al. 2012; Jacobs et al. 1976).

Numerous studies detected MTX in municipal WWTP influents with concentrations ranging from 2.6 to $59 \mathrm{ng} / \mathrm{L}$ in Canada (Garcia-Ac et al. 2009b) and Spain (Martín et al. 2014; Negreira et al. 2014). Castiglioni et al. (2005) detected MTX at 12.6 
$\mathrm{ng} / \mathrm{L}$ in one of eight samples of WWTP effluent, showing a partial removal of this contaminant. Around hospital areas, the level of concentration could be higher: in hospital effluent, maximum concentrations can reach concentration levels of 4,689 ng/L in China (Yin et al. 2010), 300 ng/L in Taiwan (Lin et al. 2014) and even 28,700 ng/L in France (Catastini et al. 2008). These high concentrations are not only related to hospital with specialized oncology area, because MTX is also used for other treatments such as polyarthritis rheumatoid. Catastini et al. (2008) detected even $2000 \mathrm{ng} / \mathrm{L}$ in WWTP influent, which was connected to hospitals and $30 \mathrm{ng} / \mathrm{L}$ in the WWTP effluent, showing incomplete removal by the wastewater treatment process. Thus, MTX and some known transformation products could enter in the environment, but there is a lack of knowledge about their occurrence in drinking and surface waters.

MTX can be partially degraded through various processes, particularly during wastewater or drinking water treatment. Kiffmeyer et al. (1998) reported the biodegradation of MTX in eight days by an activated sludge system with an efficiency of 95\% and identified 7-OH-MTX as the main TP. The concentration of this TP increased with the same rate as the MTX concentration decreased, indicating that it did not undergo further biodegradation. Recently, Isidori et al. (2016) observed the transformation of MTX into 7-OH-MTX in hospital effluent transiting to a WWTP by potential biotic conversion. Kosjek et al. (2015) have shown that MTX was readily biodegradable by activated sludge and transformed into several TPs. They have identified 8 new TPs resulting from demethylation, oxidative cleavage of amine, cleavage of $\mathrm{C}-\mathrm{N}$ bond, aldehyde to carboxylate transformation and hydroxylation. DAMPA was the most abundant and persistent TP. These results contrast with a previous study by Henschel et al. (1997) with OECD 301 biodegradability test, which classified MTX as not readily biodegradable. After using the same OECD standardized procedure, Lutterbeck et al. (2015) proceeded to photo-irradiation at 200-400 nm wavelengths on the biodegradation mixture. They identified nine products including 7-OH-MTX and DAMPA, indicating that they did not undergo further degradation. Calza et al. (2014) identified seven photoproducts resulting from irradiation at $360 \mathrm{~nm}$, with transformation involving decarboxylation and hydroxylation or the molecule cleavage. The addition of titanium dioxide favoured a supplementary transformation pathway by the elimination of succinic acid from MTX. Lai et al. (2017) studied the role of bicarbonate anions in MTX photocatalysis by UV-TiO 2 treatment. Transformations included the addition of atomic oxygen, hydroxylation, deamination, C-C cleavage and C-N cleavage of the aniline moiety, this last one being proposed as the primary degradation pathway. Upon the 16 TPs identified in this study, six were new whereas the others were common with previous photodegradation studies (Calza et al. 2014; Lutterbeck et al. 2015). Hsu et al. (2019) studied the self-sensitized degradation mechanism and pathways through direct photolysis and identified 10 TPs common to the study by Lai et al. (2017). Finally, Roig et al. (2014) identified chlorination products during the treatment water process. Toxicity bioassays with Vibrio Fischeri have shown a decrease in toxicity under direct photolysis (Calza et al. 2014; Lutterbeck et al.2015), while an increase in toxicity was seen during photodegradation in presence of bicarbonate anions (Lai et al. 2017).

In summary, various studies focussed on the MTX photodegradation, but none compared its reactivity in terms of degradation kinetics and/or transformation pathways, according neither to the wavelength nor the $\mathrm{pH}$. Furthermore, various TPs issuing from MTX through abiotic (photodegradation or various AOPs) and biotic processes were evidenced and presented a high variability according to the studies.

The goal of this research was to disclose the MTX photodegradation under conditions occurring 1) in natural surface waters, thus receiving solar light (using 300-450 nm emitting lamps, i.e. using the photoactive part of the solar spectrum) and 2) during drinking water treatment, thus using $254 \mathrm{~nm}$ irradiation. Focusing on direct photolysis processes, experiments were realised in pure water to allow the identification of TPs. The $\mathrm{pH}$ was varied $(\mathrm{pH} 3$ and 7$)$ to study changes in reactivity according to the two ionization states of MTX. In addition, cytotoxicity assessment of TPs mixture was conducted during the photodegradation experiment at $\mathrm{pH} 7$ under both irradiation conditions. This study aimed to complement the existing knowledge since the photodegradation of MTX is not documented at low wavelengths, focussing on the degradation kinetics of MTX, the identification of TPs and the evolution of cytotoxicity following MTX photodegradation. Our analytical strategy included the usage of mass spectrometry in both positive and negative modes to have multiple arguments for structural identification of the TPs. 


\section{Experimental}

\section{Chemicals and reagents}

MTX (MTX, CAS 59-05-2, > 98\%) was obtained from Sigma Aldrich (St Quentin Fallavier, France), perchloric acid $\left(\mathrm{HClO}_{4}\right.$ 70\%-72\%) and $\mathrm{NaOH} 1 \mathrm{~mol} / \mathrm{L}$ from Merk (Darmstadt, Germany). $\mathrm{HCl} 1 \mathrm{~mol} / \mathrm{L}$ was prepared from a commercial 37\% solution (Carlo Erba, Val de Reuil, France). Water was supplied by a Milli-Q water system (Millipore, Saint-Quentin-en-Yvelines, France) at a quality of resistivity $>18.2$ Mohm.cm and total organic carbon $<3 \mu \mathrm{g} / \mathrm{L}$. The analyses were performed using formic acid (98\%-100\%, Sigma Aldrich), acetonitrile (RS plus gradient, Carlo Erba) and methanol (RPE, Carlo Erba).

\section{Photodegradation experiments}

The degradation experiments were conducted using an initial MTX concentration of $40 \mu \mathrm{M}$ by dilution from an alkaline aqueous stock solution prepared every two weeks. Selecting this concentration allowed monitoring the parent evolution, detecting and identifying the TPs without sample pre-concentration. The pH was set at 7 or 3 by the addition of $0.05 \mathrm{M} \mathrm{HClO}_{4}$ or $\mathrm{NaOH}$. The solutions were kept in the dark before the experiments. During reactions, samples were withdrawn at specified times and stored in the dark at $10^{\circ} \mathrm{C}$ until their analysis by liquid chromatography HPLC-UV.

Two wavelength conditions, representative of natural conditions in surface water (300-450 nm) and drinking water treatment $(254 \mathrm{~nm}$ ) were used. For the $300-450 \mathrm{~nm}$ treatment, $150 \mathrm{~mL}$ of solution was placed in a 3-cm internal diameter tubular pyrex-reactor at the center of a cylindrical device equipped with six lamps emitting within 300 to $450 \mathrm{~nm}$ with a maximum emission at $365 \mathrm{~nm}$ (TLD $15 \mathrm{~W}$, Philips). A fan located outside the bottom of the tube was used to remove heat from the reactor, thus allowing the experiments to be conducted at an ambient temperature of $20-22{ }^{\circ} \mathrm{C}$. The fan and lamps were turned on for at least 30 minutes before the start of each experiment. Light intensity measured by a radiometer (VLX-3W, Vilber Lourmat, Marne-la-Vallée, France) was for each of the six lamps ca $0.1 \mathrm{~mW} / \mathrm{cm}^{2}$ at $312 \mathrm{~nm}$ and $1.2 \mathrm{~mW} / \mathrm{cm}^{2}$ at 365 $\mathrm{nm}$. The MTX solution was bubbled by a $150 \mathrm{~mL} / \mathrm{min}$ flow of air during $20 \mathrm{~min}$ before exposition and during the irradiation. For the $254 \mathrm{~nm}$ treatment, a quartz cylindrical 2-cm internal diameter tubular photoreactor containing $60 \mathrm{~mL}$ solution was placed parallel to a monochromatic low-pressure mercury lamp (TUV 15 W, Philips) outputting a $254 \mathrm{~nm}$ light intensity of 1.5 $\mathrm{mW} / \mathrm{cm}^{2}$ at the photoreactor location. The solution was mixed by magnetic stirring. To determine the quantum yields, the UV spectra of initial solutions were recorded in quartz cuvettes using a spectrophotometer (UV-2401 PC, Shimadzu).

\section{Analytical determinations}

High Performance liquid chromatography with ultraviolet detection (HPLC-UV) for MTX monitoring

The reaction monitoring was performed by HPLC-UV to establish rapidly the MTX degradation kinetics, before HPLC-MS (/MS) to characterize the photodegradation mixture in terms of TPs. The HPLC-UV were carried out using a Waters Alliance (2690/5) system on a HPLC C18 Gravity-SB column $150 \times 3$ mm, $3 \mu \mathrm{m}$ particle size (Macherey-Nagel). The gradient profile started at $97 \%$ water with $0.05 \%$ formic acid and linearly progressed up to $50 \%$ in 30 min, the second solvent being acetonitrile, at a constant flow rate of $0.5 \mathrm{~mL} / \mathrm{min}$. The detection was performed using diode-array detector (TUV 2489, Waters) acquiring data in the $230-305 \mathrm{~nm}$ range. Data were acquired and treated using Empower software. Quantifications were performed at $305 \mathrm{~nm}$, using the $40 \mu \mathrm{M}$ initial solution (mean of 4 injections for each experiment) as $100 \%$ abundance. All the peak areas were expressed in percentage of initial MTX. The MTX kinetics of degradation were treated as a first order form. The apparent first-order rate constants $k^{\prime}$ were evaluated according to $\operatorname{Ln}\left(C / C_{0}\right)=-k^{\prime} t$, where $C$ is the MTX concentration at time $\mathrm{t}$ and $\mathrm{C}_{0}$ its initial concentration.

\section{UHPLC-ESI-MS for TPS monitoring}

The TPs were monitored by Ultra High Performance Liquid Chromatography (UHPLC) - mass spectrometry (MS). The device consisted on an Acquity UPLC system (Waters, Milford, MA, USA) composed of a high pressure binary solvent manager, an 
autosampler and a column oven connected to a triple quadrupole mass spectrometer (TQD, Waters). Chromatographic separation was carried out on a UPLC C18 Gravity-SB Column, $100 \times 2$ mm, $1.8 \mu \mathrm{m}$ particle size (Macherey-Nagel). The gradient profile started at $97 \%$ water with $0.05 \%$ formic acid for 5 min, linearly progressed to $50 \%$ at 30 min, with a flow rate of $0.3 \mathrm{~mL} / \mathrm{min}$. The UHPLC effluent was directed to an UV detector (TUV, Waters) programmed at $305 \mathrm{~nm}$, prior to its introduction into the mass spectrometer via an electrospray source operating either in positive or negative mode. The electrospray conditions were: capillary voltage $3 \mathrm{kV}$, cone voltage $40 \mathrm{~V}$ and $54 \mathrm{~V}$ respectively under positive and negative modes, source temperature $150^{\circ} \mathrm{C}$, desolvation temperature $450^{\circ} \mathrm{C}$, extractor voltage $3 \mathrm{~V}$, cone and desolvation gas flow (nitrogen) at 20 and $900 \mathrm{~L} / \mathrm{h}$, respectively. LC-MS studies were carried out in full scan MS over the mass range of $\mathrm{m} / \mathrm{z} 120-$ 550. For quantitation, the integrations were performed on pseudo-molecular ions.

\section{Pre-concentration by Solid Phase Extraction (SPE)}

To perform the structural determinations of the TPs, a pre-concentration was necessary. Each reaction was stopped at an irradiation time selected as a compromise between the variety of observed TPs and their relative abundance. The obtained solutions were then submitted to Solid Phase Extraction (SPE), using various conditions to maximize the TP extraction on the lipophilic/hydrophilic balance Oasis HLB $\left(200 \mathrm{mg}, 6 \mathrm{~mL}\right.$ ) cartridge. $\mathrm{Na}_{2}$ EDTA was added to the samples with a suitable volume of a $0.1 \mathrm{M}$ solution to achieve a final concentration of $0.1 \%$ (gram Na${ }_{2}$ EDTA per gram solution) to improve the extraction efficiency of target compounds according to Ferrando-Climent et al. (2013). The elution was done with $4 \mathrm{~mL}$ of methanol.

\section{UHPLC-ESI-MS/MS for identification}

Structural elucidation of TPs was achieved with an ultra-high performance liquid chromatograph Ultimate 3000 (Thermo Fisher Scientific) coupled to a Q Exactive hybrid quadrupole - Orbitrap ${ }^{\text {TM }}$ (Thermo Fisher Scientific) mass spectrometer through a Heated Electrospray Ionization (HESI-II) probe. The chromatographic separation of the samples was performed on the same UPLC column and the same gradient as previously in UHPLC-ESI-MS. The analyses were performed in positive and negative modes under the following specific conditions: spray voltage, $\pm 3 \mathrm{kV}$; sheath gas pressure: 35 psi, auxiliary gas flow rare: 10 (arbitrary units); ion transfer tube and vaporizer temperature $300^{\circ} \mathrm{C}$. Nitrogen was employed as sheath and auxiliary gas.

MS data were acquired in full scan within mass-to-charge $(\mathrm{m} / \mathrm{z})$ range of $120-550 \mathrm{~m} / \mathrm{z}$ at a mass resolution of 70000 and a scanning speed of 3.7 scan/s. It allowed detecting the pseudo-molecular ions $[\mathrm{M}+\mathrm{H}]^{+}$and $[\mathrm{M}-\mathrm{H}]^{-}$of the various compounds, and thus their elemental composition. The pseudo-molecular ions were fragmented by higher-energy collisional dissociation (HCD) with normalized collision energy of 35\% and then diriged to the Orbitrap where they were analysed with a resolution of 35000. Xcalibur ${ }^{\mathrm{TM}}$ software (Thermo Fisher Scientific) was employed for instrumental control and data processing.

\section{In vitro cell-proliferation assay}

Lung carcinoma (A549) cells were grown in DMEM (Dulbecco's Modified Eagle Medium) supplemented with 10\% of fetal calf serum (FCS) and $100 \mathrm{U} / \mathrm{mL}$ penicillin and $100 \mu \mathrm{g} / \mathrm{mL}$ streptomycin (Invitrogen) in a 5\% CO2 and 95\% hygrometry environment at $37^{\circ} \mathrm{C}$.

The cytotoxic activity of MTX was investigated using the MTS ((3-(4,5-dimethylthiazol-2-yl)-5-(3-carboxymethoxyphenyl)-2-(4sulfophenyl)-2H-tetrazolium)) method (Promega). $2.510^{3}$ cells $(100 \mu \mathrm{L})$ were seeded in 96 -well plates and incubated overnight at $37{ }^{\circ} \mathrm{C}$ in presence of $5 \% \mathrm{CO}_{2}$ and $95 \%$ hygrometry. Then, the cells were treated with $100 \mathrm{~mL}$ of MTX at different final concentrations (from $50 \mathrm{mM}$ to $0.05 \mathrm{nM}$ ). After $72 \mathrm{~h}$, the media was aspirated and $100 \mu \mathrm{L}$ of a MTS solution ( $10 \%$ in media) were added in each well. After a $3 \mathrm{~h}$ incubation period at $37{ }^{\circ} \mathrm{C}$ in presence $5 \% \mathrm{CO}_{2}$ and $95 \%$ hygrometry, the optical density was measured at $490 \mathrm{~nm}$ wavelength using a microplate reader (Infinite M200 Pro, Tecan trading AG, Switzerland). Untreated cells were used as control. Each concentration was tested in six replicates and the experiment was fulfilled in 
triplicates. The concentration inhibiting $50 \%$ of the cell proliferation $\left(\mathrm{IC}_{50}\right)$ was determined using GraphPad Prism (GraphPad Software Inc, San Diego, CA, USA). To evaluate the cytotoxicity evolution along the MTX degradation at pH 7, different timepoints were chosen for the two irradiation conditions: treatment at $254 \mathrm{~nm}$, time-points: $t=0,60,180$ and 360 min; treatment at 300-450nm, time-points: $t=0,60,120$ and $180 \mathrm{~min}$. Each sample was then evaluated using the method described above with $100 \mathrm{~mL}$ of each solution at the final concentration of $100 \mathrm{nM}$ (close value of the $\mathrm{IC}_{50}$ determined for MTX).

\section{Results And Discussion}

\section{Kinetics of MTX degradation and evolution of TPs}

When the MTX aqueous solutions at pH 7 or 3 were placed in the dark, they remained stable for at least a $24 \mathrm{~h}$ period. Irradiated at $254 \mathrm{~nm}$ during $3 \mathrm{~h}$, the MTX degraded up to ca $40 \%$ and $27 \%$ residual MTX at pH 7 and 3 , respectively (Fig. 1 a). The reactions being conducted in MilliQ water without any photo-inducer, they can be interpreted as direct photolysis. The kinetics followed a pseudo-first-order with regression coefficients greater than $r^{2}$ of 0.99 , and the constants were determined as $8.8 \pm 1.610^{-5} \mathrm{~s}^{-1}$ and $12.4 \pm 0.710^{-5} \mathrm{~s}^{-1}$ (mean \pm standard deviation, $\mathrm{n}=3$ ) at $\mathrm{pH} 7$ and 3 , respectively (Fig.2 a). The significantly faster reactivity at $\mathrm{pH} 3$ resulted from a different ionic form, as $\mathrm{MTX}$ is a polyelectrolyte with $3 \mathrm{p} K_{\mathrm{a}}$ at $3.36,4.70$, and 5.71 (Rubino, 2001). The change in photoreactivity with the ionic form has been widely observed for numerous compounds, and frequently linked with a change of the quantum yield (Chowdhury et al. 2020). However, the MTX UVabsorption spectrum sharply changes between the two $\mathrm{pH}$, presenting around $254 \mathrm{~nm}$ a minimum at $\mathrm{pH} 3$ when MTX is a cation and a maximum at $\mathrm{pH} 7$ when $\mathrm{MTX}$ is an anion (SI, Fig. S1). As a result, the quantum yields appeared to be similar at $\mathrm{pH} 7$ and 3 , around $1.310^{-3}$ because of the differences in molar absorptivity at $254 \mathrm{~nm}$ (Fig. 2 b).

The MTX photodegradation was also performed at both $\mathrm{pH} 7$ and 3 under $300-450 \mathrm{~nm}$ wavelength range. At pH 3 , the MTX degradation was slower than at $254 \mathrm{~nm} \mathrm{pH} 3$, with pseudo-kinetic constant $\left(2.7 \pm 0.910^{-5} \mathrm{~s}^{-1}, \mathrm{n}=4\right)$ (Fig. 2 a) determined with regression coefficients in the 0.94-0.98 $\left(r^{2}\right)$ range, and quantum yield $\left(1.7 \pm 0.710^{-4}\right)$ significantly different (Fig. 2 b). At $\mathrm{pH} 7$, the overall degradation kinetics appeared as comparable to the $254 \mathrm{~nm}$ ones, with a pseudo-first-order kinetic constant calculated as $12.8 \pm 0.910^{-5} \mathrm{~s}^{-1}(\mathrm{n}=5)$ and a quantum yield not significantly different from $254 \mathrm{~nm} \mathrm{pH} 7\left(1.05 \pm 0.110^{-3}\right)$ (Fig. $2 \mathrm{a}$ and b). However, the regression coefficients were lower than in the other conditions (0.86 to 0.92$)\left(r^{2}\right)$ because of an important initial lag phase more pronounced than at pH 3 (Fig. 1b). Chatterii and Gallelli (1977) observed the same lag phase and explained it by the accumulation of free radical produced by bicarbonates introduced in the solution, but in this study, such important free radical production could not be expected in Milli-Q water. At high initial concentration of MTX and with an irradiation wavelength comparable to ours, Hsu et al. (2019) also observed the initial lag phase. They demonstrated that it was due to a self-sensitized photodegradation mechanism: MTX enhanced its own direct photolysis, increasing thus the degradation rate through the production of the triplet-excited state of methotrexate $\left({ }^{3} \mathrm{MTX} \mathrm{X}^{\star}\right)$ and the triplet-excited state of pteridine derivatives, whereas the produced singlet oxygen quenched degradation. This self-sensitized degradation mechanism probably explains why we observed higher degradation rate (and thus quantum yield) at $\mathrm{pH} 7$ than at $\mathrm{pH} 3$. This assumption is furthermore supported by the protonation site located on the diamino-pteridine and corresponding to the dissociation constant ( $\mathrm{p} K_{\mathrm{a}}$ ) of 5.71 (Poe, 1977; Rubino, 2001).

\section{Structural identification of photodegradation products}

The elemental composition of the various compounds and of their main fragment ions are summarized in Table 1. Due to the lack of standards corresponding to most of the hypothesized photoproducts: 1) a comprehensive study of the MTX fragmentation was conducted and 2) most of the identifications corresponded to a level $2 \mathrm{~b}$ (otherwise specified) according to the Schymanski et al. (2014) classification.

In the positive mode, the MTX fragmentation pathways have been found to be consistent with the literature (Calza et al. 2014; Lutterbeck et al. 2015; Lai et al. 2017; Hsu et al. 2019; Kosjek et al. 2015). The higher-energy collisional dissociation (HCD) of 
$[\mathrm{M}+\mathrm{H}]^{+}$produced the ion $\mathrm{m} / \mathrm{z} 308$ by the cleavage of the amide bond between the glutamic and p-methylaminobenzoic acid residues. From this $\mathrm{m} / \mathrm{z} 308$ ion, the cleavage of the $\mathrm{C}-\mathrm{N}$ bond between $\mathrm{p}$-methylaminobenzoyl and diaminopteridinemethylene groups produced the ions m/z 175 and 134. In the negative mode, unexplored to our knowledge, three fragmentation pathways were distinguished (Fig.3 and Fig. S2). The first fragmentation may correspond to the elimination of $\mathrm{H}_{2} \mathrm{O}$ to form $\mathrm{m} / \mathrm{z} 435$ or to the elimination of $\mathrm{CO}_{2}$ from the glutamic acid group, giving ion at $\mathrm{m} / \mathrm{z} 409$. This $\mathrm{m} / \mathrm{z} 409$ ion further evolved through elimination of $\mathrm{H}_{2} \mathrm{~N}-\mathrm{CN}$ to form $\mathrm{m} / \mathrm{z} 367$, through $\mathrm{N}-\mathrm{C}$ cleavage to form $\mathrm{m} / \mathrm{z} 235$ and then through $\mathrm{CO}_{2}$ elimination to form $\mathrm{m} / \mathrm{z}$ 191. An alternative and major MTX fragmentation pathway was interpreted through a rearrangement initiated by the hydroxyl group from the carboxylic acid linked to the benzamide derivative, forming a fivecentered transition state before the elimination of 3-oxoaziridin-2-yl-propanoic acid as proposed by Secrétan et al. (2018) for pemetrexed. An alternative mechanism leading to the same m/z 324 ion was also proposed in the case of pralatrexate, including a N-C cleavage followed by rearrangement (Sastry et al. 2016). The obtained ion $\mathrm{m} / \mathrm{z} 324$, which presents the same structure as $[\mathrm{M}-\mathrm{H}]-$ of DAMPA, may further eliminate $\mathrm{CO}_{2}$ (to form $\mathrm{m} / \mathrm{z} 280$ ) or produce the radical ions $\mathrm{m} / \mathrm{z} 149,174$ and 189 (through $\mathrm{m} / \mathrm{z} 280$ rearrangement) by heterolytic cleavage.

In the positive mode, most of the TPs (TP324, TP424a, TP424b, TP408a) presented the fragment ions $\mathrm{m} / \mathrm{z} 308,175$ and 134 , or at least for the lower mass TPs the ion m/z 134 (TP280, TP250). Being respectively characteristics of the diaminopteridine and $\mathrm{N}$-methylaminobenzoic acid parts of the original MTX, the ions m/z 175 and 134 suggested that those parts were unchanged, and m/z 308 comforted both were unchanged. In contrast, TP440 HCD spectrum presented m/z 175 ion (thus intact diamino pteridine group), but m/z 294 and 120 instead of m/z 308 and 134. The -14 Da shift was proved to be due to a $\mathrm{CH}_{2}$ difference from MTX according to the elemental composition. This was thus due to the demethylation of the $\mathrm{N}$ methyl bridge. Accordingly, TP266, which presents a 14 Da mass lower than TP280 and a m/z 120 ion, should be 2-(4aminobenzamido)pentanedioic acid and results from N-demethylation of TP280 (Calza et al. 2014). The TP408b also presented the fragments $\mathrm{m} / \mathrm{z} 294$ and 120 showing its demethylation of the $\mathrm{N}$-methyl bridge; its identification will be presented below. The lower mass TPs corresponding to pteridine derivatives, TP 206 and TP 208, were identified according to their positive mass spectra as corresponding to already known structures (Lutterbeck et al. 2015; Calza et al. 2014; Lai et al. 2017; Kosjek et al. 2015). Both spectra contained the same $\mathrm{m} / \mathrm{z} 163$ ion $\left(\mathrm{C}_{6} \mathrm{H}_{7} \mathrm{~N}_{6}{ }^{+}\right)$resulting either from loss of $\mathrm{CO}_{2}$ for TP 206 or successive losses of $\mathrm{H}_{2} \mathrm{O}(\mathrm{m} / \mathrm{z}$ 191) and CO for TP 208. This two pteridine derivatives could explain the lag phase observed in the kinetic studies and explained by a self-sensitized degradation mechanism (Hsu et al. 2019). Indeed, in the first hour of MTX degradation, the abundance of these two TPs was higher under 300-450 nm pH 7 than under $254 \mathrm{~nm} \mathrm{pH} 7$.

Only ESI-positive mode is generally studied, which appeared to be more sensitive and suitable for both the parent compound and for most of the photogenerated products (Calza et al. 2014). However, the fragmentation in negative mode gives useful information about the glutamic acid part. For instance, TP280, $\mathrm{C}_{13} \mathrm{H}_{16} \mathrm{~N}_{2} \mathrm{O}_{5}$, could eliminate consecutively two $\mathrm{CO}_{2}$ molecules, forming m/z 235 and then m/z 191 ions. As observed for MTX, a rearrangement can lead to the formation of ion $\mathrm{m} / \mathrm{z}$ 150. These two fragmentation pathways indicate that the glutamic part of TP280 is unchanged, leading to its identification as 2-(4-(methylamino)benzamido)pentanedioic acid. TP250, whose chemical formula indicates that it differs from TP280 with a loss of $\mathrm{CH}_{2} \mathrm{O}$, can also be identified on the basis of its fragments in negative mode. The fragment $\mathrm{m} / \mathrm{z}$ 149 indicates that the methylamino part was conserved, as this ion is 4-(methylamino)benzoylamide. The loss concerned the glutamic acid part, as proven by the ion 4-oxobut-2-enoate at $\mathrm{m} / \mathrm{z} 99$. Such ions $\mathrm{m} / \mathrm{z} 99$ and 149 were also observed in TP424a and TP424b spectra, indicating that both result from MTX oxidation, formally by loss of formaldehyde from the glutamic acid in a and g position. The identification of TP250, TP424a and TP424b are of Schymanski level 3, as no indication is available to attribute the a or g position. Two isomers TP408a and TP408b were also identified at level 3 . The compound TP408a resulted from MTX loss of $\mathrm{HCOOH}$. Its isomer TP408b, N-demethylated according to the positive mode, presented the same $\mathrm{m} / \mathrm{z}$ 363, 321, 189 and 174 ions as TP408a, but also as major ions m/z 309 and 267 (absent in the TP408a spectrum). Those ions indicate that the glutamic acid part of MTX was in TP408b transformed into amino-pentenoic acid (SI, Fig. S3 and S4). Finally, TP324, which presented the fragments m/z 149 and 174 previously mentioned, was identified (at level 2b) as the 4-(((2,4-diaminopteridin-6-yl)methyl)(methyl)amino)benzamide. 
Among these eleven identified TPs, only six have been evidenced previously (Calza et al. 2014; Kosjek et al. 2015; Lutterbeck et al. 2015; or Lai et al. 2017): TP206, TP 208, TP 280, TP 266, TP 324 and TP440 (Fig. 4). In summary, three degradation pathways can be distinguished: $\mathrm{N}$-demethylation of the bridge and $\mathrm{C}-\mathrm{N}$ cleavage between $\mathrm{p}$-methylaminobenzoyl and diaminopteridinemethylene groups, previously known, and glutamic acid oxidation evidenced in this study.

\section{Evolution of cytotoxicity at $\mathrm{pH} 7$}

The $\mathrm{IC}_{50}$ of MTX against $\mathrm{A} 549$ cancer cells was determined as $120 \pm 20.0 \mathrm{nM}$. Consistently, at $100 \mathrm{~nm}$ and before photodegradation, the viability of cancer cells was close to $50 \%$ (Fig. 5). Then, for both irradiation wavelengths, the viability increased as the percentage of MTX decreased, indicating that TPs formed during irradiation at $\mathrm{pH} 7$ were less cytotoxic than the parent compound. For the 300-450 nm treatment, the two pteridine derivatives, TP 208 and TP 206, were the main photoproducts. While MTX fully disappeared after $3 \mathrm{~h}$ of irradiation, both TPs persisted in solution, even if TP 208 decreased. Meanwhile, the viability reached 100\%, showing the TPs innocuity on A549 cancer cells (Fig. 5 a). At 254 nm, in addition of these same TP 208 and TP 206, TP 424 also accumulated after $5 \mathrm{~h}$ of irradiation (with an equivalent of $18 \%$ of residual MTX). The slower degradation of MTX and the presence of TP 424 could explain that complete viability was not retrieved (90.61 $\pm 4.18 \%$ ) (Fig. 5b). TP280, TP266 and TP250 were not detected with the irradiation at pH 7, but this monitoring was done without preconcentration step (by SPE) therefore their presence at trace level cannot be excluded.

Calza et al. (2014) demonstrated that TPs formed during photodegradation in pure water were less toxic than MTX and identified TP 208 as a major photoproduct. Lutterbeck et al. (2015) concluded that the intermediates formed during the reaction were less toxic than the parent compound, which included TP206 and TP208. However, these results were obtained in Vibrio Fischeri bioassays and did not focus on the anticancer activity of MTX as proposed herein.

\section{Conclusion}

Under different irradiation conditions, MTX photodegradation can produce a large variety of TPs. The kinetics showed that photodegradation was the fastest under environmental conditions $(300-450 \mathrm{~nm}, \mathrm{pH} 7)$ with only $7 \%$ of residual MTX after 4 h of irradiation. Nevertheless, not only the residual MTX is of environmental concern and several TPs were monitored and characterized. LC-HRMS allowed identifying eleven photoproducts, including five compounds, which were not mentioned in previous studies. The identification of these uncommon TPs was allowed by the use of mass spectrometry in the negative mode and evidenced the important oxidation degradation pathway of the glutamic acid part. The decrease in cytotoxicity during MTX degradation demonstrated that TPs formed in pure water at $\mathrm{pH} 7$ are less cytotoxic than the parent compound. Nevertheless, the well-known TPs of MTX, DAMPA and 7-OH-MTX, were not observed in our irradiation conditions.

Even though our experiments attempt to mimic the photodegradation that occurs in natural water or wastewater treatment, one needs to be aware that the formation of TPs highly depends on the composition of water, as well as the concentration of the parent compound. It is therefore well possible that MTX phototransformation products identified in our study appeared only as transient species in other aqueous matrices than pure water. Therefore, further investigations are necessary to estimate the occurrence of the identified TPs and their effects in natural and waste waters. This implies to further develop analytical methods to identify and quantify these TPs in natural matrices.

\section{Declarations}

\section{Ethics approval and consent to participate: Not applicable}

Consent for publication: Not applicable

Availability of data and materials: The datasets used and/or analysed during the current study are available from the corresponding author on reasonable request. 
Competing interests: The authors declare that they have no competing interests

Funding: This research is a part of the EDIFIS project funded by a grant from the French National Agency for Research (ANR16-CE34-0001-01). The research was also supported by grants from INRAE (Environment and Agronomy division) and the French ministry of Agriculture and Food for AE PhD scholarships.

Authors' contributions: Conception and design were performed by $\mathrm{AE}$ and $\mathrm{SN}$, with supervision by PB and RL. RL, PB and SN acquired fundings. Material preparation, data collection and analysis were performed by $A E$, as well as PL for exact mass analysis and CS for cytotoxicity. Data interpretations were performed by AE and SN, with help of other authors. The first draft of the manuscript was written by $A E$ and all authors commented on previous versions of the manuscript. All authors read and approved the final manuscript.

Acknowledgements: The authors are grateful to Edwige Kouadio for her work on the initial analytical developments and structural identifications to Brigitte Pollet for her help on exact mass analysis.

\section{References}

aus der Beek T, Weber FA, Bergmann A, Hickmann S, Ebert I, Hein A, Küster A (2016) Pharmaceuticals in the environmentGlobal occurrences and perspectives: Pharmaceuticals in the global environment. Environ Toxicol Chem 35:823-835. https://doi.org/10.1002/etc.3339

Benotti MJ, Trenholm RA, Vanderford BJ, Holady JC, Stanford BD, Snyder SA (2009) Pharmaceuticals and Endocrine Disrupting Compounds in U.S. Drinking Water. Environ. Sci Technol 43:597-603. https://doi.org/10.1021/es801845a

Besse JP, Latour JF, Garric J (2012) Anticancer drugs in surface waters. Environ Internat 39:73-86. https://doi.org/10.1016/j.envint.2011.10.002

Breithaupt H, Küenzlen E, Goebel G (1982) Rapid high-pressure liquid chromatographic determination of methotrexate and its metabolites 7-hydroxymethotrexate and 2,4-diamino-N10-methylpteroic acid in biological fluids. Anal Biochem 121:103-113. https://doi.org/10.1016/0003-2697(82)90562-0

Buerge IJ, Buser HR, Poiger T, Müller MD (2006) Occurrence and Fate of the Cytostatic Drugs Cyclophosphamide and Ifosfamide in Wastewater and Surface Waters. Environ Sci Technol 40:7242-7250. https://doi.org/10.1021/es0609405

Calza P, Medana C, Sarro M, Rosato V, Aigotti R, Baiocchi C, Minero C (2014) Photocatalytic degradation of selected anticancer drugs and identification of their transformation products in water by liquid chromatography-high resolution mass spectrometry. J Chromatogr A 1362:135-144. https://doi.org/10.1016/j.chroma.2014.08.035

Castiglioni S, Bagnati R, Calamari D, Fanelli R, Zuccato E (2005) A multiresidue analytical method using solid-phase extraction and high-pressure liquid chromatography tandem mass spectrometry to measure pharmaceuticals of different therapeutic classes in urban wastewaters. J Chromatogr A 1092:206-215. https://doi.org/10.1016/j.chroma.2005.07.012

Catastini C, Mullot JU, Boukari S, Mazellier P, Levi Y, Cervantes P, Ormsby JN (2008) Identification de molécules anticancéreuses dans les effluents hospitaliers. Eur J Water Qual 39:171-180. https://doi.org/10.1051/water/2008004

Chatterji DC, Gallelli JF (1977) High-pressure liquid chromatographic analysis of methotrexate in presence of its degradation products. J Pharm Sci 66:1219-1222. https://doi.org/10.1002/jps.2600660904

Chowdhury P, Sarathy SR, Das S, Li J, Ray AK, Ray MB (2020) Direct UV photolysis of pharmaceutical compounds: Determination of pH-dependent quantum yield and full-scale performance. Chem Eng J 380:122460. https://doi.org/10.1016/j.cej.2019.122460 
Donehower RC, Hande KR, Drake JC, Chabner BA (1979) Presence of 2,4-diamino-N ${ }^{10}$-methylpteroic acid after high-dose methotrexate. Clin Pharmacol Ther 26:63-72. https://doi.org/10.1002/cpt197926163

Escher BI, Fenner K (2011) Recent Advances in Environmental Risk Assessment of Transformation Products. Environ Sci Technol 45:3835-3847. https://doi.org/10.1021/es1030799

Ferrando-Climent L, Rodriguez-Mozaz S, Barceló D (2013) Development of a UPLC-MS/MS method for the determination of ten anticancer drugs in hospital and urban wastewaters, and its application for the screening of human metabolites assisted by information-dependent acquisition tool (IDA) in sewage samples. Anal Bioanal Chem 405:5937-5952.

https://doi.org/10.1007/s00216-013-6794-4

Garcia-Ac A, Segura PA, Gagnon C, Sauvé S (2009a) Determination of bezafibrate, methotrexate, cyclophosphamide, orlistat and enalapril in waste and surface waters using on-line solid-phase extraction liquid chromatography coupled to polarityswitching electrospray tandem mass spectrometry. J Environ Monit 11:830-838. https://doi.org/10.1039/b817570e

Garcia-Ac A, Segura PA, Viglino L, Fürtös A, Gagnon C, Prévost M, Sauvé S (2009b) On-line solid-phase extraction of largevolume injections coupled to liquid chromatography-tandem mass spectrometry for the quantitation and confirmation of 14 selected trace organic contaminants in drinking and surface water. J Chromatogr A 1216:8518-8527.

https://doi.org/10.1016/j.chroma.2009.10.015

Henschel KP, Wenzel A, Diedrich M, Fliedner A (1997) Environmental Hazard Assessment of Pharmaceuticals. Regul Toxicol Pharmacol 25:220-225. https://doi.org/10.1006/rtph.1997.1102

Hsu MH, Tsai CJ, Lin AYC (2019) Mechanism and pathways underlying the self-sensitized photodegradation of methotrexate under simulated solar irradiation. J Hazard Mater 373:468-475. https://doi.org/10.1016/j.jhazmat.2019.03.095

Isidori M, Lavorgna M, Russo C, Kundi M, Žegura B, Novak M, Filipič M, Mišík M, Knasmueller S, de Alda ML, Barceló D, Žonja B, Česen M, Ščančar J, Kosjek T, Heath E (2016) Chemical and toxicological characterisation of anticancer drugs in hospital and municipal wastewaters from Slovenia and Spain. Environ Pollut 219:275-287.

https://doi.org/10.1016/j.envpol.2016.10.039

Jacobs SA, Stoller RG, Chabner BA, Johns DG (1976) 7-Hydroxymethotrexate as a urinary metabolite in human subjects and rhesus monkeys receiving high dose methotrexate. J Clin Invest 57:534-538. https://doi.org/10.1172/JCl108308

Kiffmeyer T, Götze HJ, Jursch M, Lüders U (1998) Trace enrichment, chromatographic separation and biodegradation of cytostatic compounds in surface water. Fresenius J Anal Chem 361:185-191. https://doi.org/10.1007/s002160050859

Kosjek T, Negreira N, de Alda ML, Barceló D (2015) Aerobic activated sludge transformation of methotrexate: Identification of biotransformation products. Chemosphere 119:S42-S50. https://doi.org/10.1016/j.chemosphere.2014.04.081

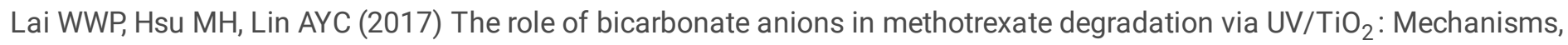
reactivity and increased toxicity. Water Res 112:157-166. https://doi.org/10.1016/j.watres.2017.01.040

Lin AYC, Lin YC, Lee WN (2014) Prevalence and sunlight photolysis of controlled and chemotherapeutic drugs in aqueous environments. Environ Pollut 187:170-181. https://doi.org/10.1016/j.envpol.2014.01.005

Lutterbeck CA, Baginska E, Machado ÊL, Kümmerer K (2015) Removal of the anti-cancer drug methotrexate from water by advanced oxidation processes: Aerobic biodegradation and toxicity studies after treatment. Chemosphere 141:290-296. https://doi.org/10.1016/j.chemosphere.2015.07.069

Martín J, Camacho-Muñoz D, Santos JL, Aparicio I, Alonso E (2014) Occurrence and ecotoxicological risk assessment of 14 cytostatic drugs in wastewater. Water Air Soil Pollut 225:1896. https://doi.org/10.1007/s11270-014-1896-y

Page $10 / 16$ 
Mompelat S, Thomas O, Le Bot B (2011) Contamination levels of human pharmaceutical compounds in French surface and drinking water. J Environ Monit 13:2929-2939. https://doi.org/10.1039/c1em10335k

Negreira N, de Alda ML, Barceló D (2014) Cytostatic drugs and metabolites in municipal and hospital wastewaters in Spain: Filtration, occurrence, and environmental risk. Sci Tot Environ 497-498:68-77.

https://doi.org/10.1016/j.scitotenv.2014.07.101

Poe M (1977) Acidic dissociation constants of folic acid, dihydrofolic acid, and methotrexate. J Biol Chem 252:3724-3728. https://doi.org/10.1016/S0021-9258(17)40312-7

Roig B, Marquenet B, Delpla I, Bessonneau V, Sellier A, Leder C, Thomas O, Bolek R, Kummerer K (2014) Monitoring of methotrexate chlorination in water. Water Res 57:67-75. https://doi.org/10.1016/j.watres.2014.03.008

Rubino FM (2001) Separation methods for methotrexate, its structural analogues and metabolites. J Chromatogr B Biomed Sci App 764:217-254. https://doi.org/10.1016/S0378-4347(01)00402-9

Sabry SM, Abdel-Hady M, Elsayed M, Fahmy OT, Maher HM (2003) Study of stability of methotrexate in acidic solution Spectrofluorimetric determination of methotrexate in pharmaceutical preparations through acid-catalyzed degradation reaction. J Pharm Biomed Anal 32:409-423. https://doi.org/10.1016/S0731-7085(03)00239-5

Sastry RVRP, Venkatesan CS, Sastry BS, Mahesh K (2016) Identification and characterization of forced degradation products of pralatrexate injection by LC-PDA and LC-MS. J Pharm Biomed Anal 131:400-409.

https://doi.org/10.1016/j.jpba.2016.08.023

Schymanski EL, Jeon J, Gulde R, Fenner K, Ruff M, Singer HP, Hollender J (2014) Identifying Small Molecules via High Resolution Mass Spectrometry: Communicating Confidence. Environ Sci Technol 48:2097-2098.

https://doi.org/10.1021/es5002105

Secrétan PH, Karoui M, Levi Y, Sadou-Yayé H, Tortolano L, Solgadi A, Yagoubi N, Do B (2018) Pemetrexed degradation by photocatalytic process: Kinetics, identification of transformation products and estimation of toxicity. Sci Tot Environ 624:1082-1094. https://doi.org/10.1016/j.scitotenv.2017.12.182

Turci R, Sottani C, Spagnoli G, Minoia C (2003) Biological and environmental monitoring of hospital personnel exposed to antineoplastic agents: a review of analytical methods. J Chromatogr B 789:169-209. https://doi.org/10.1016/S15700232(03)00100-4

Widemann BC, Sung E, Anderson L, Salzer WL, Balis FM, Monitjo KS, McCully C, Hawkins M, Adamson PC (2000) Pharmacokinetics and metabolism of the methotrexate metabolite 2, 4-diamino-N(10)-methylpteroic acid. J Pharmacol Exp Ther 294:894-901.

Yin J, Shao B, Zhang J, Li K (2010) A Preliminary Study on the Occurrence of Cytostatic Drugs in Hospital Effluents in Beijing, China. Bull Environ Contam Toxicol 84:39-45. https://doi.org/10.1007/s00128-009-9884-4

Zounková R, Odráška P, Dole alová L, Hilscherová K, Maršálek B, Bláha L (2007) Ecotoxicity and genotoxicity assessment of cytostatic pharmaceuticals. Environ Toxicol Chem 26:2208-2214. https://doi.org/10.1897/07-137R.1

\section{Table}

Table 1 Accurate mass measurements in the positive and negative modes determined by LC-Q-Orbitrap-MS in MS or MS/MS mode

Page $11 / 16$ 


\begin{tabular}{|c|c|c|c|c|c|c|c|c|c|c|}
\hline \multicolumn{6}{|c|}{ Positive mode } & \multicolumn{5}{|c|}{ Negative mode } \\
\hline \multirow[t]{2}{*}{ compound } & nominal & formula & {$[\mathrm{M}+\mathrm{H}]^{+}$} & {$[\mathrm{M}+\mathrm{H}]^{+}$} & error & nominal & formula & {$[\mathrm{M}-\mathrm{H}]^{-}$} & {$[\mathrm{M}-\mathrm{H}]^{-}$} & error \\
\hline & $\begin{array}{l}\text { ion } \\
\text { mass }\end{array}$ & & $\begin{array}{c}\text { accurate } \\
\text { mass }\end{array}$ & theoretical & (ppm) & $\begin{array}{l}\text { ion } \\
\text { mass }\end{array}$ & & $\begin{array}{c}\text { accurate } \\
\text { mass }\end{array}$ & theoretical & (ppm) \\
\hline \multirow[t]{2}{*}{ TP 206} & 207 & $\mathrm{C}_{7} \mathrm{H}_{7} \mathrm{~N}_{6} \mathrm{O}_{2}{ }^{+}$ & 207.0621 & 207.0625 & 1.93 & & & & & \\
\hline & 163 & $\mathrm{C}_{6} \mathrm{H}_{7} \mathrm{~N}_{6}+$ & 163.0724 & 163.0727 & 1.84 & & & & & \\
\hline \multirow[t]{3}{*}{ TP 208} & 209 & $\mathrm{C}_{7} \mathrm{H}_{9} \mathrm{~N}_{6} \mathrm{O}_{2}{ }^{+}$ & 209.0778 & 209.0782 & 1.91 & & & & & \\
\hline & 191 & $\mathrm{C}_{7} \mathrm{H}_{7} \mathrm{~N}_{6} \mathrm{O}^{+}$ & 191.0673 & 191.0676 & 1.57 & & & & & \\
\hline & 163 & $\mathrm{C}_{6} \mathrm{H}_{7} \mathrm{~N}_{6}{ }^{+}$ & 163.0724 & 163.0727 & 1.84 & & & & & \\
\hline \multirow[t]{3}{*}{ TP 250} & 251 & $\mathrm{C}_{12} \mathrm{H}_{15} \mathrm{~N}_{2} \mathrm{O}_{4}{ }^{+}$ & 251.1026 & 251.1026 & 0.00 & 249 & $\mathrm{C}_{12} \mathrm{H}_{13} \mathrm{~N}_{2} \mathrm{O}_{4}^{-}$ & 249.0881 & 249.0881 & 0.00 \\
\hline & 134 & $\mathrm{C}_{8} \mathrm{H}_{8} \mathrm{NO}^{+}$ & 134.0600 & 134.0606 & 4.48 & 149 & $\mathrm{C}_{8} \mathrm{H}_{9} \mathrm{~N}_{2} \mathrm{O}^{-}$ & 149.0715 & 149.0720 & 3.35 \\
\hline & & & & & & 99 & $\mathrm{C}_{4} \mathrm{H}_{3} \mathrm{O}_{3}^{-}$ & 99.0082 & 99.0088 & 6.06 \\
\hline \multirow[t]{6}{*}{ TP 266} & 267 & $\mathrm{C}_{12} \mathrm{H}_{15} \mathrm{~N}_{2} \mathrm{O}_{5}{ }^{+}$ & 267.0968 & 267.0976 & 3.00 & 265 & $\mathrm{C}_{12} \mathrm{H}_{13} \mathrm{~N}_{2} \mathrm{O}_{5}{ }^{-}$ & 265.0830 & 265.0830 & 0.00 \\
\hline & 120 & $\mathrm{C}_{7} \mathrm{H}_{6} \mathrm{NO}^{+}$ & 120.0445 & 120.0444 & -0.83 & 221 & $\mathrm{C}_{11} \mathrm{H}_{13} \mathrm{~N}_{2} \mathrm{O}_{3}^{-}$ & 221.0927 & 221.0926 & -0.45 \\
\hline & 92 & $\mathrm{C}_{6} \mathrm{H}_{6} \mathrm{~N}^{+}$ & 92.0500 & 92.0495 & -5.43 & 128 & $\mathrm{C}_{5} \mathrm{H}_{6} \mathrm{NO}_{3}^{-}$ & 128.0343 & 128.0348 & 3.91 \\
\hline & & & & & & 177 & $\mathrm{C}_{10} \mathrm{H}_{13} \mathrm{~N}_{2} \mathrm{O}^{-}$ & 177.1026 & 177.1028 & 1.13 \\
\hline & & & & & & 135 & $\mathrm{C}_{7} \mathrm{H}_{7} \mathrm{~N}_{2} \mathrm{O}^{-}$ & 135.0554 & 135.0558 & 2.96 \\
\hline & & & & & & 92 & $\mathrm{C}_{6} \mathrm{H}_{6} \mathrm{~N}^{-}$ & 92.0493 & 92.0500 & 7.60 \\
\hline \multirow[t]{4}{*}{ TP 280} & 281 & $\mathrm{C}_{13} \mathrm{H}_{17} \mathrm{~N}_{2} \mathrm{O}_{5}{ }^{+}$ & 281.1124 & 281.1132 & 2.85 & 279 & $\mathrm{C}_{13} \mathrm{H}_{15} \mathrm{~N}_{2} \mathrm{O}_{5}{ }^{-}$ & 279.0985 & 279.0987 & 0.72 \\
\hline & 134 & $\mathrm{C}_{8} \mathrm{H}_{8} \mathrm{NO}^{+}$ & 134.0601 & 134.0600 & -0.75 & 235 & $\mathrm{C}_{12} \mathrm{H}_{15} \mathrm{~N}_{2} \mathrm{O}_{3}^{-}$ & 235.1085 & 235.1088 & 1.28 \\
\hline & & & & & & 191 & $\mathrm{C}_{11} \mathrm{H}_{15} \mathrm{~N}_{2} \mathrm{O}^{-}$ & 191.1183 & 191.1190 & 3.66 \\
\hline & & & & & & 150 & $\mathrm{C}_{8} \mathrm{H}_{8} \mathrm{NO}_{2}^{-}$ & 150.0551 & 150.0561 & 6.66 \\
\hline \multirow[t]{5}{*}{ TP 324} & 325 & $\mathrm{C}_{15} \mathrm{H}_{17} \mathrm{~N}_{8} \mathrm{O}^{+}$ & 325.1520 & 325.1520 & -0.06 & 323 & $\mathrm{C}_{15} \mathrm{H}_{15} \mathrm{~N}_{8} \mathrm{O}^{-}$ & 323.1374 & 323.1374 & 0.09 \\
\hline & 308 & $\mathrm{C}_{15} \mathrm{H}_{14} \mathrm{~N}_{7} \mathrm{O}^{+}$ & 308.1254 & 308.1254 & 0.10 & 281 & $\mathrm{C}_{14} \mathrm{H}_{13} \mathrm{~N}_{6} \mathrm{O}^{-}$ & 281.1151 & 281.1151 & -0.07 \\
\hline & 175 & $\mathrm{C}_{7} \mathrm{H}_{7} \mathrm{~N}_{6}{ }^{+}$ & 175.0727 & 175.0727 & -0.17 & 174 & $\mathrm{C}_{7} \mathrm{H}_{6} \mathrm{~N}_{6}^{-{ }^{\circ}}$ & 174.0654 & 174.0654 & -0.06 \\
\hline & 160 & $\mathrm{C}_{7} \mathrm{H}_{6} \mathrm{~N}_{5}{ }^{+}$ & 160.0618 & 160.0618 & -0.19 & 149 & $\mathrm{C}_{8} \mathrm{H}_{9} \mathrm{~N}_{2} \mathrm{O}^{-}$ & 149.0715 & 149.0720 & 3.62 \\
\hline & 134 & $\mathrm{C}_{8} \mathrm{H}_{8} \mathrm{NO}^{+}$ & 134.0600 & 134.0600 & 0.30 & 133 & $\mathrm{C}_{8} \mathrm{H}_{7} \mathrm{NO}^{-}$ & 133.0528 & 133.0533 & 3.83 \\
\hline \multirow[t]{5}{*}{ TP 408a } & 409 & $\mathrm{C}_{19} \mathrm{H}_{21} \mathrm{~N}_{8} \mathrm{O}_{3}{ }^{+}$ & 409.1721 & 409.1731 & 2.44 & 407 & $\mathrm{C}_{19} \mathrm{H}_{19} \mathrm{~N}_{8} \mathrm{O}_{3}^{-}$ & 407.1588 & 407.1586 & -0.49 \\
\hline & 308 & $\mathrm{C}_{15} \mathrm{H}_{14} \mathrm{~N}_{7} \mathrm{O}^{+}$ & 308.1251 & 308.1254 & 0.97 & 321 & $\mathrm{C}_{17} \mathrm{H}_{17} \mathrm{~N}_{6} \mathrm{O}^{-}$ & 321.1473 & 321.1469 & -1.25 \\
\hline & 175 & $\mathrm{C}_{7} \mathrm{H}_{7} \mathrm{~N}_{6}{ }^{+}$ & 175.0727 & 175.0727 & 0.00 & 363 & $\mathrm{C}_{18} \mathrm{H}_{19} \mathrm{~N}_{8} \mathrm{O}^{-}$ & 363.1692 & 363.1687 & -1.38 \\
\hline & 134 & $\mathrm{C}_{8} \mathrm{H}_{8} \mathrm{NO}^{+}$ & 134.0602 & 134.0600 & -1.49 & 189 & $\mathrm{C}_{11} \mathrm{H}_{13} \mathrm{~N}_{2} \mathrm{O}^{-}$ & 189.1028 & 189.1033 & 2.64 \\
\hline & & & & & & 174 & $\mathrm{C}_{7} \mathrm{H}_{6} \mathrm{~N}_{6}{ }^{\circ-}$ & 174.0654 & 174.0654 & 0.00 \\
\hline \multirow[t]{8}{*}{ TP 408b } & 409 & $\mathrm{C}_{19} \mathrm{H}_{21} \mathrm{~N}_{8} \mathrm{O}_{3}{ }^{+}$ & 409.1721 & 409.1731 & 2.44 & 407 & $\mathrm{C}_{19} \mathrm{H}_{19} \mathrm{~N}_{8} \mathrm{O}_{3}^{-}$ & 407.1588 & 407.1586 & -0.49 \\
\hline & 294 & $\mathrm{C}_{14} \mathrm{H}_{12} \mathrm{~N}_{7} \mathrm{O}^{+}$ & 294.1090 & 294.1098 & 2.72 & 363 & $\mathrm{C}_{18} \mathrm{H}_{19} \mathrm{~N}_{8} \mathrm{O}^{-}$ & 363.1689 & 363.1687 & -0.55 \\
\hline & 175 & $\mathrm{C}_{7} \mathrm{H}_{7} \mathrm{~N}_{6}{ }^{+}$ & 175.0722 & 175.0727 & 2.86 & 321 & $\mathrm{C}_{17} \mathrm{H}_{17} \mathrm{~N}_{6} \mathrm{O}^{-}$ & 321.1468 & 321.1469 & 0.31 \\
\hline & 120 & $\mathrm{C}_{7} \mathrm{H}_{6} \mathrm{NO}^{+}$ & 120.0445 & 120.0444 & -0.83 & 309 & $\mathrm{C}_{14} \mathrm{H}_{13} \mathrm{~N}_{8} \mathrm{O}^{-}$ & 309.1219 & 309.1218 & -0.32 \\
\hline & & & & & & 267 & $\mathrm{C}_{13} \mathrm{H}_{11} \mathrm{~N}_{6} \mathrm{O}^{-}$ & 267.1001 & 267.1000 & -0.37 \\
\hline & & & & & & 189 & $\mathrm{C}_{11} \mathrm{H}_{13} \mathrm{~N}_{2} \mathrm{O}^{-}$ & 189.1027 & 189.1033 & 3.17 \\
\hline & & & & & & 174 & $\mathrm{C}_{7} \mathrm{H}_{6} \mathrm{~N}_{6} \cdot-$ & 174.0653 & 174.0659 & 3.45 \\
\hline & & & & & & 99 & $\mathrm{C}_{4} \mathrm{H}_{3} \mathrm{O}_{3}^{-}$ & 99.0076 & 99.0088 & 12.12 \\
\hline \multirow[t]{6}{*}{ TP 424a } & 425 & $\mathrm{C}_{19} \mathrm{H}_{21} \mathrm{~N}_{8} \mathrm{O}_{4}{ }^{+}$ & 425.1667 & 425.1680 & 3.06 & 423 & $\mathrm{C}_{19} \mathrm{H}_{19} \mathrm{~N}_{8} \mathrm{O}_{4}^{-}$ & 423.1539 & 423.1535 & -0.95 \\
\hline & 308 & $\mathrm{C}_{15} \mathrm{H}_{14} \mathrm{~N}_{7} \mathrm{O}^{+}$ & 308.1249 & 308.1254 & 1.62 & 323 & $\mathrm{C}_{15} \mathrm{H}_{15} \mathrm{~N}_{8} \mathrm{O}^{-}$ & 323.1376 & 323.1374 & -0.62 \\
\hline & 175 & $\mathrm{C}_{7} \mathrm{H}_{7} \mathrm{~N}_{6}{ }^{+}$ & 175.0726 & 175.0727 & 0.57 & 281 & $\mathrm{C}_{14} \mathrm{H}_{13} \mathrm{~N}_{6} \mathrm{O}^{-}$ & 281.1158 & 281.1156 & -0.71 \\
\hline & 134 & $\mathrm{C}_{8} \mathrm{H}_{8} \mathrm{NO}^{+}$ & 134.0601 & 134.0600 & -0.75 & 174 & $\mathrm{C}_{7} \mathrm{H}_{6} \mathrm{~N}_{6}^{*-}$ & 174.0653 & 174.0654 & 0.57 \\
\hline & & & & & & 149 & $\mathrm{C}_{8} \mathrm{H}_{9} \mathrm{~N}_{2} \mathrm{O}^{-}$ & 149.0712 & 149.0720 & 5.37 \\
\hline & & & & & & 99 & $\mathrm{C}_{4} \mathrm{H}_{3} \mathrm{O}_{3}^{-}$ & 99.0077 & 99.0088 & 11.11 \\
\hline \multirow[t]{6}{*}{ TP424b } & 425 & $\mathrm{C}_{19} \mathrm{H}_{21} \mathrm{~N}_{8} \mathrm{O}_{4}{ }^{+}$ & 425.1672 & 425.1680 & 1.88 & 423 & $\mathrm{C}_{19} \mathrm{H}_{19} \mathrm{~N}_{8} \mathrm{O}_{4}^{-}$ & 423.1539 & 423.1535 & -0.95 \\
\hline & 308 & $\mathrm{C}_{15} \mathrm{H}_{14} \mathrm{~N}_{7} \mathrm{O}^{+}$ & 425.1672 & 425.1680 & 1.88 & 323 & $\mathrm{C}_{15} \mathrm{H}_{15} \mathrm{~N}_{8} \mathrm{O}^{-}$ & 323.1375 & 323.1374 & -0.31 \\
\hline & 175 & $\mathrm{C}_{7} \mathrm{H}_{7} \mathrm{~N}_{6}{ }^{+}$ & 308.1248 & 308.1254 & 1.95 & 281 & $\mathrm{C}_{14} \mathrm{H}_{13} \mathrm{~N}_{6} \mathrm{O}^{-}$ & 281.1158 & 281.1156 & -0.71 \\
\hline & 134 & $\mathrm{C}_{8} \mathrm{H}_{8} \mathrm{NO}^{+}$ & 175.0725 & 175.0727 & 1.14 & 174 & $\mathrm{C}_{7} \mathrm{H}_{6} \mathrm{~N}_{6} \cdot$ & 174.0653 & 174.0654 & 0.57 \\
\hline & & & & & & 149 & $\mathrm{C}_{8} \mathrm{H}_{9} \mathrm{~N}_{2} \mathrm{O}^{-}$ & 149.0711 & 149.0720 & 6.04 \\
\hline & & & & & & 99 & $\mathrm{C}_{4} \mathrm{H}_{3} \mathrm{O}_{3}^{-}$ & 99.0076 & 99.0088 & 12.12 \\
\hline TP 440 & 441 & $\mathrm{C}_{19} \mathrm{H}_{21} \mathrm{~N}_{8} \mathrm{O}_{5}{ }^{+}$ & 441.1628 & 441.1629 & 0.23 & 439 & $\mathrm{C}_{19} \mathrm{H}_{19} \mathrm{~N}_{8} \mathrm{O}_{5}^{-}$ & 439.1476 & 439.1484 & 1.82 \\
\hline
\end{tabular}




\begin{tabular}{|c|c|c|c|c|c|c|c|c|c|c|}
\hline & 294 & $\mathrm{C}_{14} \mathrm{H}_{12} \mathrm{~N}_{7} \mathrm{O}^{+}$ & 294.1092 & 294.1098 & 2.04 & 395 & $\mathrm{C}_{18} \mathrm{H}_{19} \mathrm{~N}_{8} \mathrm{O}_{3}-$ & 395.1583 & 395.1586 & 0.76 \\
\hline & 175 & $\mathrm{C}_{7} \mathrm{H}_{7} \mathrm{~N}_{6}{ }^{+}$ & 175.0723 & 175.0727 & 2.28 & 363 & $\mathrm{C}_{18} \mathrm{H}_{19} \mathrm{~N}_{8} \mathrm{O}^{-}$ & 363.1685 & 363.1687 & 0.55 \\
\hline & 120 & $\mathrm{C}_{7} \mathrm{H}_{6} \mathrm{NO}^{+}$ & 120.0445 & 120.0444 & -0.83 & 321 & $\mathrm{C}_{17} \mathrm{H}_{17} \mathrm{~N}_{6} \mathrm{O}^{-}$ & 321.1468 & 321.1469 & 0.31 \\
\hline & & & & & & 310 & $\mathrm{C}_{14} \mathrm{H}_{12} \mathrm{~N}_{7} \mathrm{O}_{2}-$ & 310.1058 & 310.1058 & 0.00 \\
\hline & & & & & & 266 & $\mathrm{C}_{13} \mathrm{H}_{12} \mathrm{~N}_{7}^{-}$ & 266.1159 & 266.1160 & 0.38 \\
\hline & & & & & & 221 & $\mathrm{C}_{11} \mathrm{H}_{13} \mathrm{~N}_{2} \mathrm{O}_{3}-$ & 221.0926 & 221.0926 & 0.00 \\
\hline & & & & & & 189 & $\mathrm{C}_{11} \mathrm{H}_{13} \mathrm{~N}_{2} \mathrm{O}^{-}$ & 189.1026 & 189.1033 & 3.70 \\
\hline & & & & & & 177 & $\mathrm{C}_{10} \mathrm{H}_{13} \mathrm{~N}_{2} \mathrm{O}^{-}$ & 177.1024 & 177.1028 & 2.26 \\
\hline & & & & & & 128 & $\mathrm{C}_{5} \mathrm{H}_{6} \mathrm{NO}_{3}^{-}$ & 128.0343 & 128.0353 & 7.81 \\
\hline MTX & 455 & $\mathrm{C}_{20} \mathrm{H}_{23} \mathrm{~N}_{8} \mathrm{O}_{5}{ }^{+}$ & 455.1770 & 455.1786 & 3.52 & 453 & $\mathrm{C}_{20} \mathrm{H}_{21} \mathrm{~N}_{8} \mathrm{O}_{5}{ }^{-}$ & 453.1634 & 453.1640 & 1.32 \\
\hline (454 Da) & 308 & $\mathrm{C}_{15} \mathrm{H}_{14} \mathrm{~N}_{7} \mathrm{O}^{+}$ & 308.1249 & 308.1254 & 1.62 & 435 & $\mathrm{C}_{20} \mathrm{H}_{19} \mathrm{~N}_{8} \mathrm{O}_{4}^{-}$ & 435.1530 & 435.1535 & 1.15 \\
\hline & 175 & $\mathrm{C}_{7} \mathrm{H}_{7} \mathrm{~N}_{6}{ }^{+}$ & 175.0725 & 175.0727 & 1.14 & 409 & $\mathrm{C}_{19} \mathrm{H}_{21} \mathrm{~N}_{8} \mathrm{O}_{3}-$ & 409.1743 & 409.1742 & -0.24 \\
\hline & 134 & $\mathrm{C}_{8} \mathrm{H}_{8} \mathrm{NO}^{+}$ & 134.0600 & 134.0600 & 0.00 & 367 & $\mathrm{C}_{18} \mathrm{H}_{19} \mathrm{~N}_{6} \mathrm{O}_{3}{ }^{-}$ & 367.1523 & 367.1524 & 0.27 \\
\hline & & & & & & 324 & $\mathrm{C}_{15} \mathrm{H}_{14} \mathrm{~N}_{7} \mathrm{O}_{2}^{-}$ & 324.1216 & 324.1215 & -0.31 \\
\hline & & & & & & 280 & $\mathrm{C}_{14} \mathrm{H}_{14} \mathrm{~N}_{7}^{-}$ & 280.1319 & 280.1316 & -1.07 \\
\hline & & & & & & 235 & $\mathrm{C}_{12} \mathrm{H}_{15} \mathrm{~N}_{2} \mathrm{O}_{3}{ }^{-}$ & 235.1087 & 235.1088 & 0.43 \\
\hline & & & & & & 191 & $\mathrm{C}_{11} \mathrm{H}_{15} \mathrm{~N}_{2} \mathrm{O}^{-}$ & 191.1185 & 191.1190 & 2.62 \\
\hline & & & & & & 189 & $\mathrm{C}_{11} \mathrm{H}_{13} \mathrm{~N}_{2} \mathrm{O}^{-}$ & 189.1028 & 189.1033 & 2.64 \\
\hline & & & & & & 174 & $\mathrm{C}_{7} \mathrm{H}_{6} \mathrm{~N}_{6} \cdot-$ & 174.0653 & 174.0654 & 0.57 \\
\hline & & & & & & 149 & $\mathrm{C}_{8} \mathrm{H}_{7} \mathrm{NO}_{2}{ }^{\circ-}$ & 149.0474 & 149.0482 & 5.37 \\
\hline
\end{tabular}

\section{Figures}
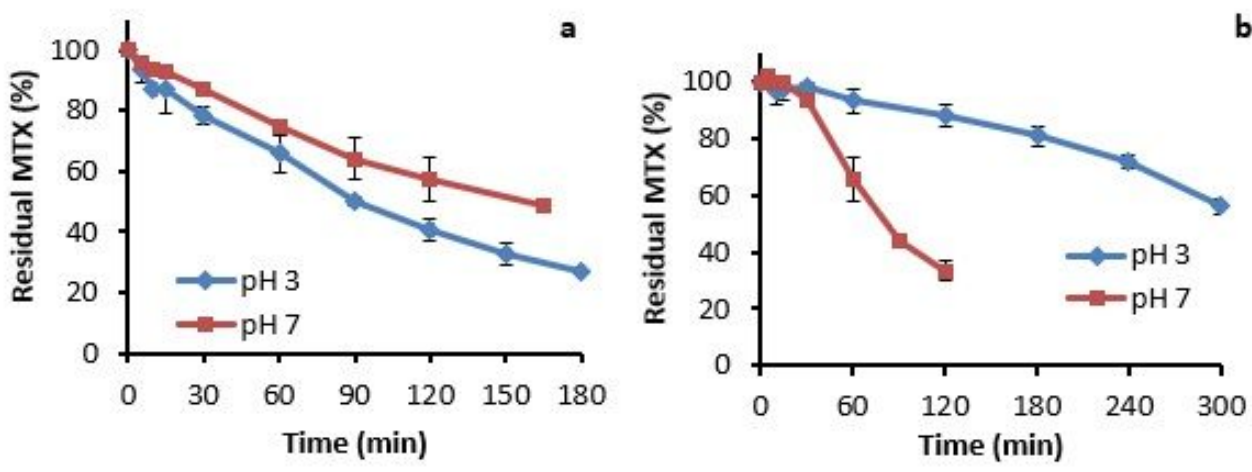

Figure 1

Methotrexate degradation kinetics under $254 \mathrm{~nm}$ (a) and 300-450 nm (b) irradiation (40 $\mu \mathrm{M}$ aqueous solutions) 

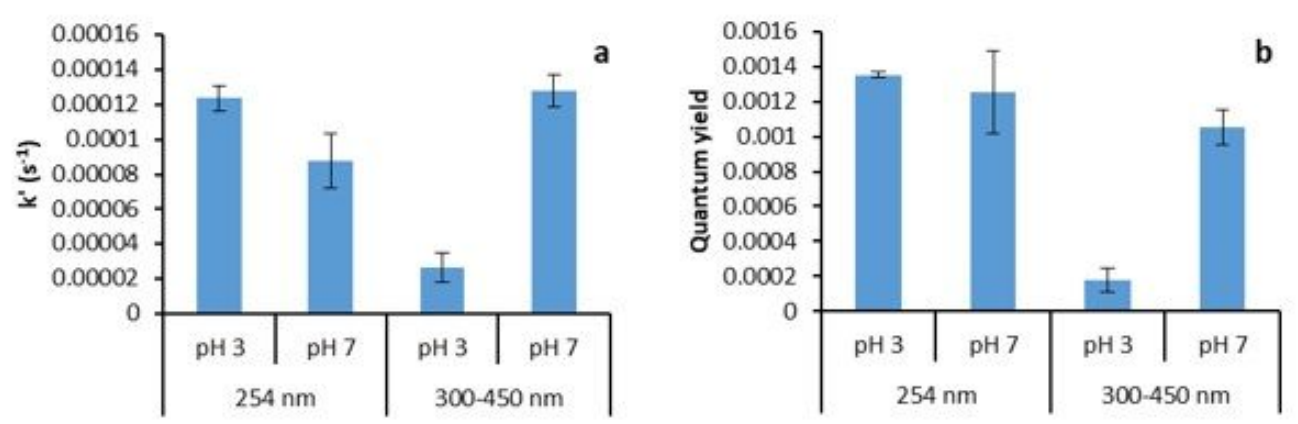

Figure 2

Pseudo-first order kinetic constants (a) and quantum yield (b) of methotrexate photodegradation

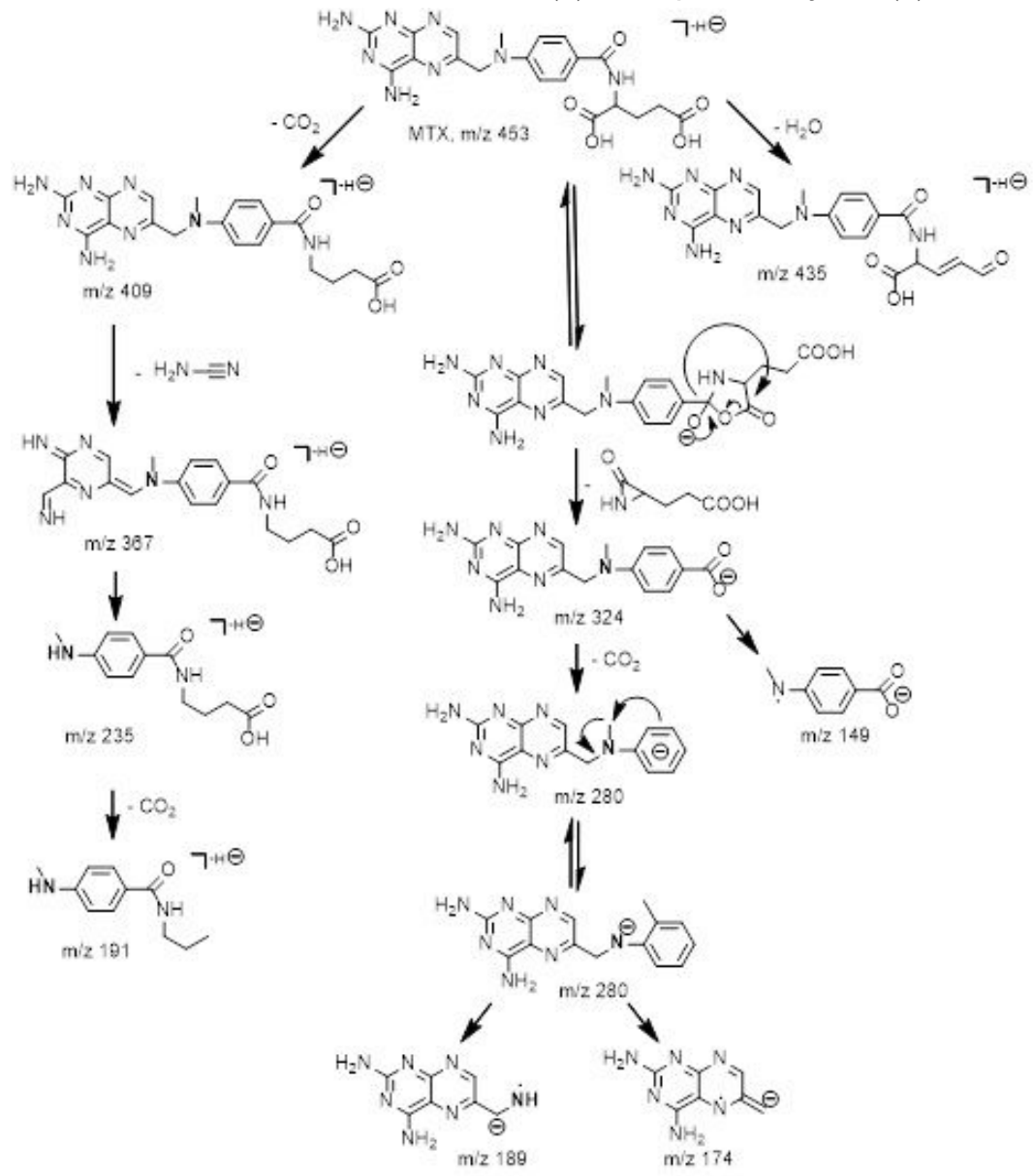

Figure 3

Methotrexate fragmentation pattern from deprotonated parent ion 


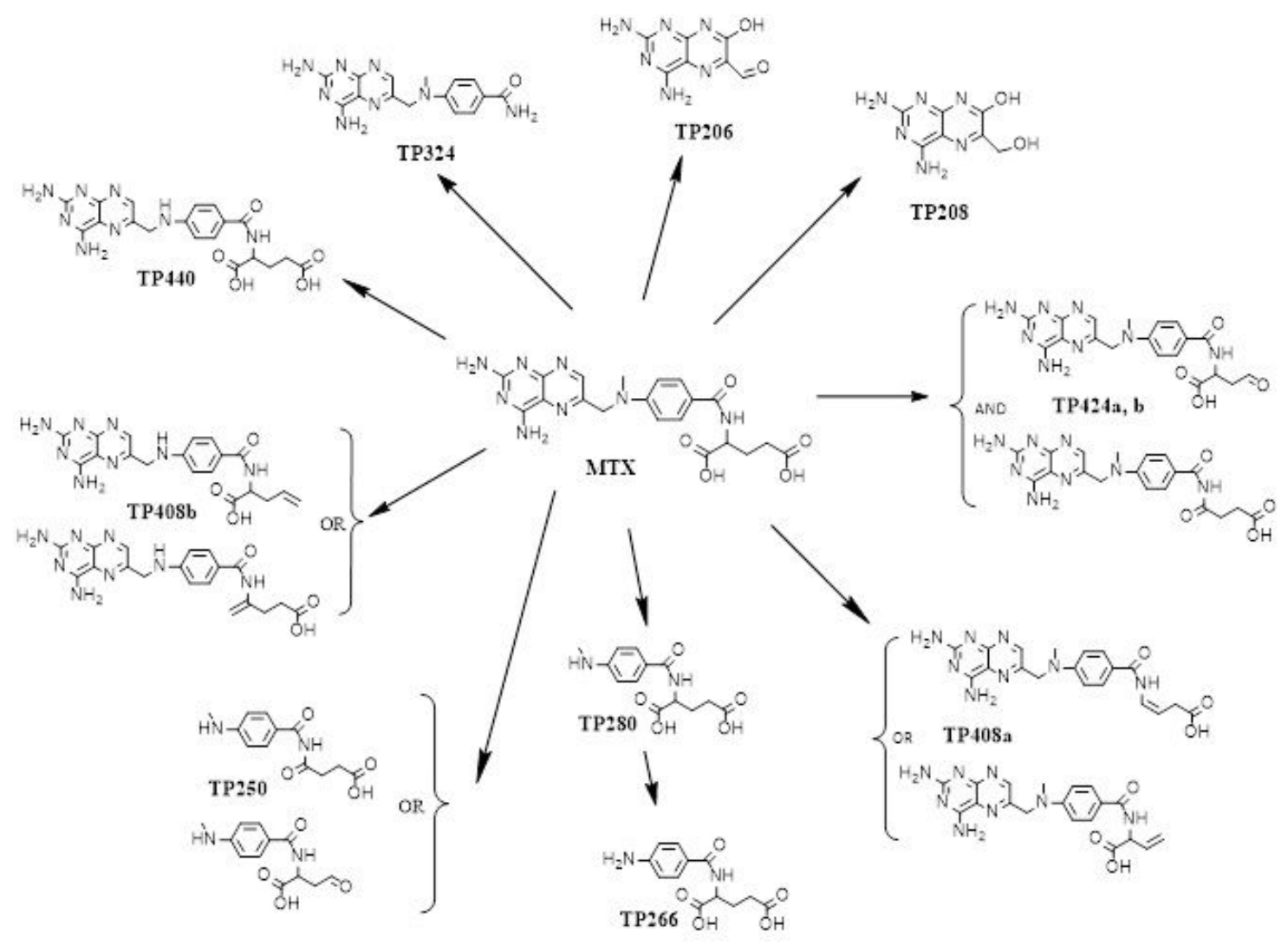

Figure 4

Proposed structures of the transformation products of MTX under irradiation
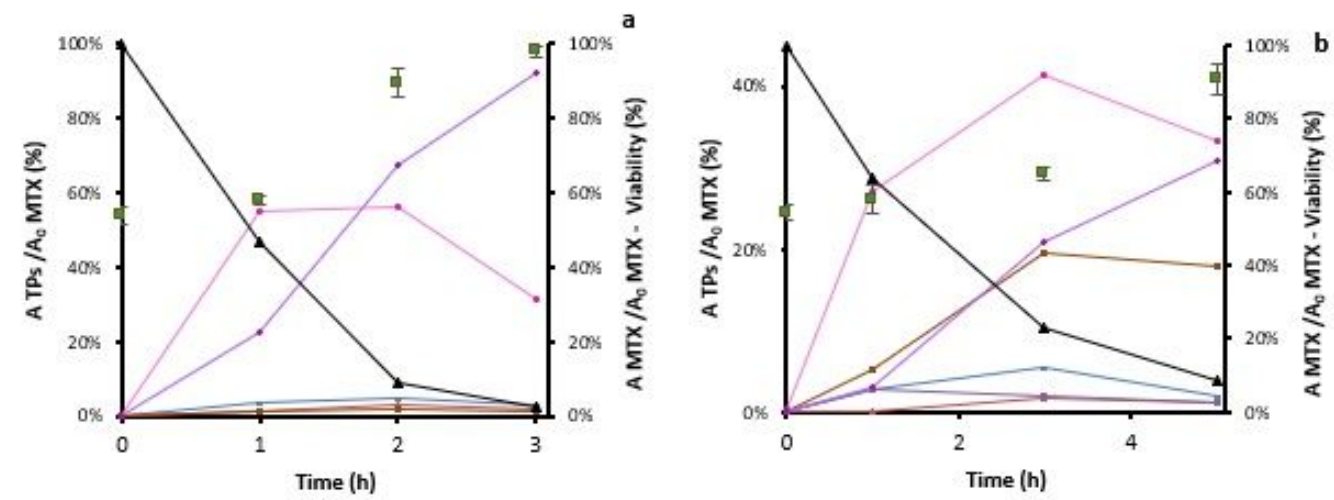

- TP324 - TP424 -

TP208 —TP206 -MTX

Viability

\section{Figure 5}

Viability evolution (\%) (green square) of cancer cells, against MTX (black line) and TPs (colored lines) evolution as function of the irradiation time: a) $300-450 \mathrm{~nm} \mathrm{pH} 7$ b) $254 \mathrm{~nm} \mathrm{pH} 7$

\section{Supplementary Files}

This is a list of supplementary files associated with this preprint. Click to download. 
- EspinosaSupplementarylnformation.pdf

Page 16/16 